\title{
Corpos e belezas midiáticas: um estudo sobre imaginário e ideologia nomanifesto tpm
}

\author{
Autora: Maria Joana Casagrande Soares-Correia \\ Orientador: Alberto Carlos Augusto Klein
}

\begin{abstract}
Resumo: O presente trabalho se propõe a estudar o imaginário e a ideologia de corpos e belezas femininos, sob o viés da sociedade midiática, a partir da análise das capas e editoriais de edições da revista Trip para Mulheres (TPM), da Editora Trip. O recorte de tempo foi delimitado de maio de 2012 a agosto de 2013, em decorrência do Manifesto TPM, descrito como um movimento contra os estereótipos e clichês contra as mulheres. Para alcançar esse objetivo, escolhermos desenvolver uma pesquisa exploratória, bibliográfica e documental, com análise de imagens. O caminho de estudo das capas foi apoiado sobre a análise iconográfica e interpretação iconológica, propostas por Panofsky (2009). O trabalho se sustenta sobre os preceitos de Estudos Culturais e visualidade, com Hall e Eagleton e Belting, CatalàDomènech e Baitello Jr.; no imaginário e imaginário midiático, propostos por Durand, Morin e Contrera; e, por fim, nos entendimentos de consumo de Haug, Baudrillard e Barbosa e Campbell. Assim, pudemos identificar que a revista TPM e seu Manifesto TPM se entendem como grandiosos e feministas, no entanto, as imagens (e mesmo alguns textos) das capas não são coerentes com esse discurso, o que nos levou a inferir que embora louvável pela proposta, o Manifesto TPM não se desvencilhou dos imaginários e ideologias vigente acerca de corpo e beleza femininos.
\end{abstract}

Palavras-chave: Corpo; Beleza; Ideologia; Imaginário midiático; Revistas femininas. 


\title{
Bodies and beauty on the media: a study on imaginary and ideology in the TPM Manifesto
}

\begin{abstract}
The aim of this paper is to study the imaginary and the ideology of female bodies and beauty, through the eyes of the media. We analyzed the covers and editorials of the magazine Trip para Mulheres (TPM), by Trip Publishing house. The clipping time was from May 2012 to August 2013, due to the TPM Manifesto, described as a move against women stereotypes and cliches. We carried out an exploratory, bibliographical and documentary research, with image analysis, in order to achieve this goal. The study of the magazine covers in this paper were based on the iconographic analysis and iconological interpretation proposed by Panofsky (2009). The work is also based on the precepts of Cultural Studies and (visual culture) visuality, by Hall \& Eagleton and Belting, CatalàDomènech and Baitello Jr.; on the imagery and media imagery, proposed by Durand, Morin and Contrera; and, finally, on the understandings of consumption by Haug, Baudrillard and Barbosa, and Campbell. Thus, we observed that the TPM magazine and its TPM Manifesto see themselves as splendid and feminist; however, the images (and even some texts) of the covers are not consistent with their argument, which led us to infer that, although commendable, the TPM Manifesto proposal did not pull away from the imaginary and current ideologies about female body and beauty.
\end{abstract}

Keywords: Body; Beauty; Ideology; Media imaginary; Women's magazine. 